\title{
THE EFFECT OF TERRORIST INCIDENTS ON CAPITAL FLOWS
}

\author{
Randall K. Filer \\ Dragana Stanišić
}

Charles University

Centerfor Economic Research and Graduate Education

Academy of Sciences of the Czech Republic

Ec onomics Institute

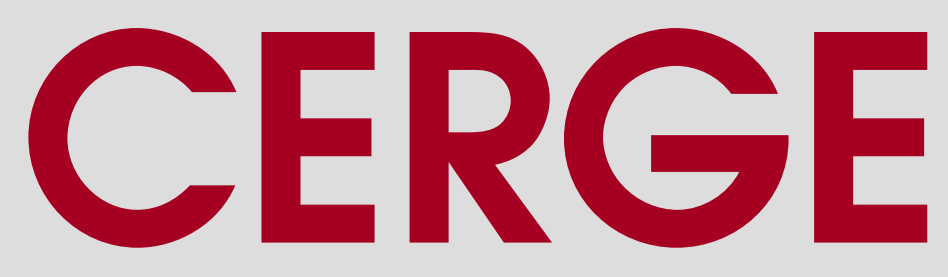




\title{
Working Paper Series $\quad 480$ (ISSN 1211-3298)
}

\section{The Effect of Terrorist Incidents on Capital Flows}

\author{
Randall K. Filer \\ Dragana Stanišić
}

\section{CERGE-EI}

Prague, January 2013 
ISBN 978-80-7343-284-3 (Univerzita Karlova. Centrum pro ekonomický výzkum a doktorské studium)

ISBN 978-80-7344-276-7 (Národohospodářský ústav AV ČR, v.v.i.) 


\title{
The Effect of Terrorist Incidents on Capital Flows*
}

\author{
Randall K. Filer \\ Hunter Collage and the Graduate Center, CUNY \\ CERGE-EI, IZA, CESifo \\ Dragana Stanišić \\ CERGE-EI
}

\begin{abstract}
The current literature shows a significant negative impact of terrorism on countries' economies. We explore this relationship in more detail. Using an unbalanced panel of over 160 countries for up to 25 years and the Global Terrorism Database (GTD) we show a decrease in FDI as a consequence of terrorism. We also find evidence that FDI flows are more sensitive to terrorism than either portfolio investments or external debt flows. Finally, we test the hypothesis that terrorism has negative spill-over effects on FDI flows into neighboring countries and find evidence that cultural but not geographical closeness matters.

Abstrakt
Současná literatura ukazuje významný negativní dopad terorismu na hospodářství zemí. V tomto článku podrobněji zkoumme tento vztah. Za použití nevyváženého panelu s více než 160 zeměmi pro období až 25 let a Databáze globálního terorismu (Global Terrorism Database - GTD) prokazujeme pokles př́mých zahraničních investic (FDI) v dusledku terorismu. FDI jsou citlivější na terorismus více než investice portfoliově nebo externí dluhové toky. Nakonec testujeme hypotézu, že terorismus má negativní efekty přelívání na FDI do sousedících zemí a docházíme k závěru, že záleží na kulturní blízkosti, ale nezáleží na zeměpisné blízkosti.
\end{abstract}

Keywords: Capital flow, terrorism, FDI, spill-over effect

JEL classification: D74, H56

\footnotetext{
*All errors remaining in this text are the responsibility of the authors.

${ }^{\dagger}$ Center for Economic Research and Graduate Education--Economics Institute, a joint workplace of Charles University in Prague and the Academy of Sciences of the Czech Republic. Address: CERGE-EI, P.O. Box 882, Politických vězňů 7, Prague 1, 111 21, Czech Republic

${ }^{\ddagger}$ Email: dstanisi@cerge-ei.cz
} 


\section{Introduction and Literature Review}

There are three major mechanisms through which foreign investors can enter domestic markets: Foreign Direct Investment (FDI), Equity Portfolio Investment and Lending (Debt). Capital inflows depend on whether investors see sufficient expected returns, given projected risk. Risk is a function of many factors including economic policies, political stability and the legal environment of the host country. Exposure to terrorism represents an additional source of risk that could significantly influence investment decisions. Surveys by the Global Business Policy Council (Abadie and Gardeazabal, 2008) report that decision-makers do take terrorism risks into account. In this paper we examine how different types of capital inflow react to terrorist incidents. We postulate that terrorist incidents introduce disruptions to economies, directly affecting the risks associated with investments. We examine whether different types of capital flow react differently to terrorism. In addition, we analyze the spillovers effect of terrorism across countries. Previous literature has focused on assessing the impact of terrorism on FDI. Abadie and Gardeazabal (2008) develop an endogenous growth model showing that the risk of terrorism significantly lowers expected returns to investments. Therefore, as a consequence of decreased expected returns, investors avoid countries where terrorist risk is high, resulting in different desired optimal levels of international investments across countries. The authors analyze how FDI changed with terrorism risk in $2003 / 2004$ for a sample of 183 countries. Terrorism risk is found to account for a small fraction of the overall risk of investment but to heavily influence FDI across countries. In a case study of Greece and Spain, Enders and Sandler (1996) estimate that these countries suffered a $13.5 \%$ and $11.9 \%$ decrease in FDI respec- 
tively as a consequence of terrorist incidents. Eckstein and Tsiddon (2004) look at the effect of terrorism on the Israeli economy and find that even though the death rate from terrorism is similar to the death rate from car accidents in Israel, terrorism affects the economy in a far more severe way. Charles and Darne (2006) focus on the September 11th, 2001 terrorist attack and its effect on stock market prices. The authors suggest that modeling of financial risks can be improved by including terrorist events. Drakos (2009) shows that daily stock market returns are significantly affected by terrorist events and that the negative effect of terrorist attacks the stock market is exacerbated by psychosocial effects.

In previous work studying the relationship between terrorism and capital flows, the most commonly used terrorism measure is the number of terrorist incidents in a country per year. One of the critiques of this measure is that it ignores information regarding the intensity of incidents (number of killed or injured) (Enders and Sandler, 1996). Thus, counting all terrorist incidents the same would imply that attacks on facilities where no one was injured or killed would convey the same signal as terrorist incidents with dozens of casualties. In addition to the number of attacks, the "terrorism risk" index has been used as a measure of terrorism in previous work (Enders and Sachsida, 2006; Abadie and Gardeazabal, 2008). It is argued that terrorism risk is a better measure because the number of attacks is a noisy measure, with too much random variation year-to-year, to capture the latent level of terrorist risk without significant measurement error and will, therefore, produce biased results (Abadie and Gardeazabal, pg.11). Reported terrorism risk as used empirically, however, shows no variation over 15 years (Abadie and Gardeazabal, 2008). Since it seems highly unlikely there has really been no change in the underlying risk in any country during this period, it seems that the terror- 
ism risk index was not updated in a Bayesian manner to include the additional information provided by new terrorist incidents.

Much of the prior literature has estimated the effect of terrorism on capital flows by examining only international terrorism (terrorist incidents where the perpetrator and target are of different nationalities). Enders and Sandler (2006) point out that this can lead to misunderstanding results for several reasons. Consider a country that experienced one international and twenty domestic terrorist incidents in a given year. In that case, considering only international incidents would attribute the entire effect to one incident instead of to the twenty-one that actually occurred. Furthermore, the country might experience only domestic terrorism and, if analysis only accounted for international incidents, any effect on capital inflows would be assigned to non-terrorism factors or the unexplained residual, even if they were actually affected by domestic terrorism. International terrorism cannot fully stand as a proxy for domestic terrorism since, as will be seen below, the correlation between these two types of events, while significant, is substantially less than $0.5 .^{1}$ Going beyond the direct effect of terrorism, very few studies have examined spill-over effects of terrorism across national borders. De Sousa, Mirza and Verdier (2010) use a trade model to incorporate spill-over effects of transnational terrorism and security on trade. They test this relationship using data on US bilateral net imports and recorded terrorist incidents against U.S targets. In addition to a negative direct impact on trade, terrorism produced a negative spillover effect on the bilateral trade in countries that are closer (sharing a border) to

\footnotetext{
${ }^{1}$ To estimate the correlation between domestic and international terrorist incidents we use Global Terrorism Database (GTD). We identify as domestic terrorism incidents events where both perpetrators and victims were of the same nationality, otherwise they are international. There were a number of incidents where one (or both) nationalities was unknown, these incidents are not included in the correlation estimate.
} 
the countries/regions where the terrorist groups are based.

\section{Research Design: Methodology, Variables, and Data}

\subsection{Methodology}

We create an unbalanced panel of more than 160 countries over 25 years and use a fixed effects regression framework. Fixed effects are desirable for two main reasons. First, country specific characteristics may be correlated with other variables and second, the sample of countries is not random. ${ }^{2}$ To study the relationship between capital flows and terrorist incidents we use two-way fixed effects. We acknowledge that the relationship between capital flows and terrorism could, in theory, be bidirectional. An inflow of foreign capital can provide additional targets as well as possibly greater resentment that serves as a motivation for attacks. On the other hand, capital inflows might increase employment and incomes, reducing a population's level of frustration. Previous literature, however, rejects reverse causality as a problem. Li and Schaub (2004) study the hypothesis that "globalization" through international trade, FDI and portfolio investment decreases the costs of international terrorism and increases the number of terrorist attacks. They find no evidence to confirm such an hypothesis. In addition, even if terrorist attacks happen more often due to the presence of foreign capital in a country, the result will be a positive bias to the coefficient on a variable (Abadie and Gardeazabal,

\footnotetext{
${ }^{2}$ A Hausman test implies the use of fixed versus random effects. Details are in the results section.
} 
2008). Based on these prior findings, we do not address reverse causality in the analysis that follows. ${ }^{3}$

\section{Baseline Specification Model}

To estimate the effect of terrorism on capital flows, controlling for the country determinants, country and year fixed effects, we use the following estimating equation:

$$
\begin{aligned}
\text { Capital Flow }_{i, t} & =\beta_{1} \text { Incidents }_{i, t}+\beta_{2}{\text { Incidents } 5 y \cdot a_{\cdot i, t}} \\
& +\mathbf{X}_{\mathbf{i}, \mathbf{t}} \gamma_{z}+u_{i, t}
\end{aligned}
$$

where Capital Flow refers to three different dependent variables: FDI, New External Debt and Portfolio Investment flows into country $i$ in time $t$; Incidents in country $i$ in time $t$ is a terrorism variable accounting for current terrorist activity relative to a country's population in millions. Incidents 5 year average is the average number of attacks in the previous five years $(t=-6$ to -1$)$ relative to the five year average population in millions. ${ }^{4}$ The vector $X$ contains country specific variables including GDP per capita, population, Financial Openness Index, and Natural Disasters. The coefficients of interest in equation (1) are $\beta_{1}$ and $\beta_{2}$. A significant negative coefficient would imply that the inflow of capital (FDI, External Debt or Portfolio Investment) in time $t$ is reduced by terrorist incidents occurring in the same year. A significant negative coefficient on $\beta_{2}$ would imply

\footnotetext{
${ }^{3}$ We did, however, conduct one crude test for endogenity. Leads of our attack variable are not related to current financial flows, with coefficients of varying sign that are never statistically significant.

${ }^{4}$ We experimented with different lengths of past activity including three and four years with no difference in results.
} 
that investors needed time to adjust plans to reflect any deterrent effect of terrorist activity. Spill-over Specification (modification of the baseline model)

In order to capture the spill-over effect of terrorist incidents on capital flows, we modify equation (1) by adding variables that capture the effects of incidents in related countries.

$$
\begin{aligned}
\text { Capital Flow }_{i, t} & =\beta_{1} \text { Incidents }_{i, t}+\beta_{2}{\text { Incidents } 5 y \cdot a_{\cdot i, t}} \\
& +\mathbf{Z}_{\mathbf{i}, \mathbf{t}} \sigma_{k}+\mathbf{X}_{\mathbf{i}, \mathbf{t}} \gamma_{z}^{\prime}+\epsilon_{i, t}
\end{aligned}
$$

where $Z$ is a vector of spill-over (neighborhood) variables.

\subsection{Variables}

\subsubsection{Terrorism Variables}

Ideally a terrorist risk index should vary over time. In addition to apparently not being updated, however, the Global Terrorism Index (GTI) used by Abadie and Gardeazaal (2008) is no longer available ${ }^{5}$ To allow the perceived risk of terrorism to vary over time and to account for the intensity of terrorist incidents we use Global Terrorism Dataset (GTD) (provided by The National Consortium for the Study of Terrorism and Responses to Terrorism $\left.(\mathrm{START})^{6}\right)$ which includes additional information on the severity of each incident. As discussed above, we created two variables, one for the average number of terrorist attacks in the five years prior

\footnotetext{
${ }^{5}$ The agency that produced this index, World Market Research Center, was acquired by Global Insight and no longer produces the index.

${ }^{6}$ http://www.start.umd.edu/gtd/about/
} 
to time $t$ and an additional variable for the number of terrorist attacks in time $t$ itself. The first variable captures historical events that could affect plans based on prior information ${ }^{7}$, while the second captures the new information provided by current events that will lead to an updating of investors' perception of risk at time $t$.

The GTD contains detailed information on over 82,000 terrorist attacks from 1970 to 2004. A terrorist incident is defined as "the threatened or actual use of illegal force and violence to attain a political, economic, religious or social goal through fear, coercion or intimidation (LaFree, 2010,p.25)." The GTD dataset does not include criminal events without an ideological or political goal or events of actual combat. (LaFree, 2010). The GTD collects event data on terrorism from sources such as Reuters, the Foreign Broadcast Information Service (FBIS), the Pinkerton Global Intelligence Service (PGIS) and its offices around the world, the US State Department reports, other US and foreign government agencies, and US and foreign newspapers including the New York Times, Financial Times, Christian Science Monitor, Washington Post, Washington Times, and Wall Street Journal (LaFree, 2010). We normalize all terrorism variables by population in millions in order to control for country size effects (i.e. twenty attacks in a country with 300 million inhabitants is different than in a country with 10 million residents). ${ }^{8}$ In order to address the intensity of attacks, we include in some specifications measures of the number of fatalities occurring in terrorist incidents. In our sample of over 160 countries during 21 years there were a total of 55, 597 terrorist incidents,

\footnotetext{
${ }^{7}$ As would implicitly be studied in prior work using the terrorism risk index.

${ }^{8}$ We do not distinguish between international and domestic terrorist attacks due to two reasons: first, there is a significant share of terrorist attacks with unknown perpetrators and victims, and second there are different definitions of international terrorism that change the number of attacks in each group.
} 
out of which only $(2,989) 5$ percent were incidents without anyone being injured or killed. ${ }^{9}$

\subsubsection{Dependent Variables - FDI flows, Portfolio Investment and Ex- ternal Debt Flows}

The data on Foreign Direct Investments (FDI) is from United Nations Conference for Trade and Development (UNCTAD), Division on Investment and Enterprise. ${ }^{10}$ FDI is defined as "investment involving a long-term relationship, reflecting a lasting interest in, and control by (10 percent ownership), a resident entity in one economy (foreign direct investor or parent enterprise) of an enterprise in a different economy (FDI enterprise or iate enterprise or foreign affiliate). Such investment involves both the initial transaction between the two entities and all subsequent transactions between them and among foreign affiliates." 11 External Debt flows are derived from the World Bank Development Indicators (WDI). ${ }^{12}$ External Debt measures external debt stocks in the private sector: Long-term private sector external debt conveys information about the distribution of long-term debt for DRS (debtor reporting system) countries by type of debtor (private banks and pri-

\footnotetext{
${ }^{9}$ The total number of people injured or killed in incidents is 279,970 , which yields approximately 5 fatalities per attack.

${ }^{10} \mathrm{http}$ ://unctad.org (United Nations Conference for Trade and Development

${ }^{11}$ The data series are FDI flows. "FDI inflows and outflows comprise capital provided (either directly or through other related enterprises) by a foreign direct investor to a FDI enterprise, or capital received by a foreign direct investor from a FDI enterprise. FDI includes the three following components: equity capital, reinvested earnings and intra-company loans. Data on FDI flows are presented on a net basis (capital transactions' credits less debits between direct investors and their foreign affiliates). Net decreases in assets or net increases in liabilities are recorded as credits, while net increases in assets or net decreases in liabilities are recorded as debits. Hence, FDI flows with a negative sign indicate that at least one of the three components of FDI is negative and not offset by positive amounts of the remaining components. These are called reverse investment or disinvestment." www.unctadstat.unctad.org

${ }^{12}$ www.worldbank.org
} 
vate entities). Long-term external debt is defined as debt that has an original or extended maturity of more than one year and that is owed to nonresidents by residents of an economy and repayable in foreign currency, goods, or services. Using the WDI data we define External Debt Flow as:

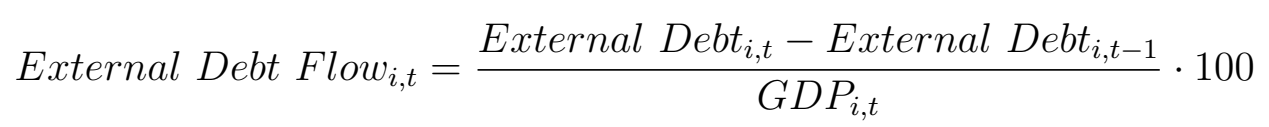

Data used to derive Portfolio Investment are also from the World Bank Development Indicators. emphPortfolio investment (equity) includes net inflows from equity securities other than those recorded as direct investment and including shares, stocks, depository receipts (American or global), and direct purchases of shares in local stock markets by foreign investors. Again using WDI data we define Portfolio Investment Flow as:

$$
\text { Portfolio Investment Flow } w_{i, t}=\frac{\text { Portfolio Inv }_{i, t}-\text { Portfolio Inv }_{\cdot i, t-1}}{G D P_{i, t}} \cdot 100
$$

\subsubsection{Spill-over Variables}

In order to account for spill-over effects we follow de Sousa et al.(2010) and use multiple different characteristics in order to define spill-overs for a given country (further referred as the "master country"). These characteristics include sharing a common religion, language, border, colonial history, or combinations of these. Thus, the "neighbors" of a given master country are any countries that share characteristics even if these are not geographically close. For example, two countries having the same majority religion could be counted as "neighbors" in the religious sense even though they are not physically close to each other. To derive the spill- 
over variables we start with a dataset where the unit of observation is a pair of countries for a given year. We then identify neighbors by a dummy variable for a given Characteristic and multiply this by the number of terrorist incidents in the neighboring country. Next, we sum the attacks for all of a particular master's neighboring countries and divide this sum by the neighboring countries' total population in millions.

$$
\text { Neighbor Effect }{ }_{i, t}=\sum \frac{\text { Characteristic }_{k} \cdot \text { Number of Incidents } s_{z, t}}{\text { Characteristic }_{k} \cdot \text { Population in Millions } \text { I }_{z, t}}
$$

$i=$ master country (capital flow recipient);

$z=$ neighboring country (by characteristic $k$ ); and

$t=$ year;

For each "master country" we define terrorist activity its "neighborhood" based on the following neighborhoods:

Border if the countries share a border with the master country;

Official Language if the countries share an official language; ${ }^{13}$

Minority Language if neighboring countries have at least $9 \%{ }^{14}$ of their population speaking the same language as the master country;

Colony ' 45 if the countries were a colony of a master country after 1945;

Common Colonizer if the countries (neighbor and master) had a common colonizer;

\footnotetext{
${ }^{13}$ We accounted for any shared official language when a country had more than one.

${ }^{14}$ For further details on language classification please see Mayer and Zignago (2011)
} 
Main Religion if a country's majority religion is the same as the main religion of the master country; ${ }^{15}$

Second Religion if a country's second largest religion is the same as a master country's main religion;

Same Region and Majority Religion if the countries are in the same region and have the same majority religion;

Border and Majority Religion if the countries share a border and have the same majority religion;

All neighboring variables have been standardized by the total population of the neighboring states so that intensity of terrorism is measured on the same scale as for the master country.

\subsubsection{Measure of Financial Openness}

In order to capture country-specific conditions in financial markets including restrictions on FDI, we use the Financial Openness Index developed by Chin and Ito (2008). This index is derived using the IMF's Annual Report on Exchange Agreements and Exchange Restrictions (AREAER) which contains information on whether a country has multiple exchange rates, restrictions on current account transactions, restrictions on capital account transactions, and requirements for the surrender to the government of currency earned through exports (Chin and

\footnotetext{
${ }^{15}$ To construct the religion dummy we assign a value of 1 if a country pair has the same main religion. The information on main religion was taken from the CIA factbook and defined as: Muslim Sunni, Muslim Shia, Muslim, Orthodox, Catholic, Anglican, Hindu, Protestant, Buddhist, Lutheran, Jewish, Evangelic.(www.cia.gov). Except in very few cases, countries have over 50 percent of population belonging to one of the twelve religious groups.
} 
Ito, 2008). Using these measures, the authors created dummy variables where 1 is assigned to cases without restrictions on each of the above four factors. ${ }^{16}$ The index is then calculated as the first standardized principal component of the four indicators, with a higher index referring to a more open economy. This index varies both across countries and over time. The advantage of the Chin-Ito index relative to other indexes of financial openness include its transparency of construction, country and time scope, and the fact that it accounts for the intensity of capital controls. In addition, compared to previous indices of financial openness that are based on interest rate parity or on arbitrage profit free conditions, the Chin-Ito index refers to actual regulatory restrictions. ${ }^{17}$

\subsection{Results}

In this section we start with baseline panel data estimates of the effect of terrorism on capital flows. Then we investigate whether there are spillover effects from terrorism in related countries. Table 1 presents an overview of all variables used in the baseline, spill-over, and robustness check estimations. Table 2 shows correlations between variables. It should be noted that that FDI, External Debt and Portfolio Equity are all negatively correlated with terrorism but only the relationship between terrorism and FDI is statistically significant. To check for multicollinearity between independent variables we use the Variance Inflation Factor (VIF). ${ }^{18}$ For independent variables in the estimated specifications reported below, VIFs are less than 5, suggesting that these variables are uncorrelated.

\footnotetext{
${ }^{16}$ Averaged over the past five year window.

${ }^{17}$ For a more complete discussion of how this index compares to other indexes in the literature, see Chin and Ito (2008)

${ }^{18}$ The square root of VIF shows how much larger a standard error is compared to the standard error in the case of uncorrelated independent variables
} 


\subsubsection{The Effect of Terrorist Incidents on Capital Flows}

We find evidence that some types of investment are more inhibited by terrorism than others. In Table 3 we show that the only significant relationship is between current attacks and conventional FDI. There is no evidence of any terrorism effect on flows of External Debt or Portfolio Investment. Columns (1), (3) and (5) report results of regressions of FDI, External Debt flows and Portfolio Investment flows on GDP per capita, population in millions, Financial Openness Index and Incidents and Incidents over the previous 5 year ${ }^{19}$. The coefficient on Incidents in column (1) is negative and significantly different from zero, this is not the case when the dependent variables are External Debt Flow (column 3) or Portfolio Investment Flow (column 5). In column (2) we include terrorism intensity variables Fatalities and Fatalities over the previous 5 years. We find no evidence for the hypothesis that the intensity of terrorist incidents explains variation in any of the capital flows once the current number of attacks have been accounted for. In light of these results, henceforth we focus only on FDI. Table 4 reports country and year fixed effects estimates. Column (1) shows regression results of FDI on terrorism variables only. On the basis of R-square we can say that terrorism alone explains 7 percent of the variance in FDI flows. In column (2) we include GDP per capita. The coefficient on Incidents remains negative and significantly different from zero, while the coefficient on Incidents over the previous 5 years is negative, much smaller, and not statistically significant. This suggests that these historical events are already included in investment stocks at time $t$, implying that current decisions are influenced only by new information derived from current terrorist

\footnotetext{
${ }^{19}$ In the estimation tables the label of this variable is Incidents 5 y.a.
} 
incidents. ${ }^{20}$ The estimations results are similar when we include measures of Financial Openness and population in column (3). The log of GDP per capita has a positive and significant coefficient that remains such with different specifications of the baseline model. The sign and significance of the population variable is similar to GDP, indicating that both larger and wealthier markets will have larger positive flows of FDI. In Table 4, column (6) we control for the number of natural disasters, which has been used in the prior literature explaining variation in FDI flows (Abadie and Gardeazabal, 2008). We find similar results that natural disasters have a negative effect on FDI flows. The R-square coefficient implies that we are now explaining about 8 percent of FDI flow variance. Overall results from Table 4 show that current terrorist incidents have a negative effect on a country's ability to attract FDI. In particular, if a country moves from the 50th to the 75th percentile in the number of attacks, FDI flows as a share of GDP fall by 0.667 percentage points ${ }^{21}$ or 25 percent $^{22}$ of average FDI flow.

\section{Spill-over effects}

Table 5 reports the results of fixed effects estimates including spill-over measures. The results show that FDI flows remain significantly negatively correlated with current terrorism across all specifications. Results in Table 5, column (1) show that sharing a border, or having the same official language or ethnic minority as a country that is affected by terrorism does not affect FDI flows into a given coun-

\footnotetext{
${ }^{20}$ We perform a Hausman test of the model specified in Table 4. and get a p-value 0.004 . Based on this result we can not reject the null hypothesis of Hausman test and, therefore, we proceed using fixed rather than random effects.

${ }^{21}$ Calculating the impact on average (13.6784-1.91)*(0.0534)

${ }^{22}\left(0.667^{*} 100\right) / 2.668$
} 
try. Results are similar in column (2) where more characteristics are introduced: including having a common colonial background, and being a colony after 1945 . Results in Table 5, column (3) show that among countries with the same majority religion, geographic proximity does not seem to matter but we can not reject the hypothesis that negative spill-over effects exist across countries sharing a religion. In column (4) the result remains robust to inclusion of combinations of characteristics, such as: countries being in the same region while sharing a religion, and sharing a border and mutual majority religion. Finally in column (5) we include all characteristics and find that results in column (4) stay significant. If a master country has the same majority religion as a country with occurrences of terrorism it will experience a drop in FDI flows. These results imply that a common religious affiliation, but not a shared physical location, creates a negative spill-over effect of terrorism on FDI flows. In addition to different specifications of the baseline model, we test for robustness by excluding the countries in the highest 10th percentile of total number of attacks distribution, and the results stay significantly different from zero at the 5 percent confidence level (coefficients remaining the same). We also estimate the baseline specification model, but instead of using levels of FDI flows as the dependent variable we use logs of FDI flows, and find similar results. The same holds if we measure terrorism by the log of the number of attacks relative to the population in millions. Besides the results presented, we augmented the specification in Table 4, column (4) by adding interaction terms between terrorism variables and governance indicators from Freedom House. ${ }^{23}$ We

\footnotetext{
${ }^{23}$ Governance indicators include: control of corruption, government effectiveness, regulatory faculty, rule of law, voice and accountability, and political stability (www.freedomhouse.org). These indicators are available from 1996 and comments regarding interaction terms refer to the period from 1996 to 2004.
} 
find no changes in our results, so we do not report the results. ${ }^{24}$

\section{Conclusion}

This study analyzes the effect of terrorist attacks on three measures of capital flows: FDI, Equity Portfolio Investment, and Lending (Debt). We apply fixed country and year effects estimation to a sample of over 160 countries over 25 years. Using a new and comprehensive terrorism database (LaFree, 2010), we find no evidence of the effect of terrorism on the flow of External Debt or Portfolio Investment. Increased terrorism activity in a country does, however, substantially decrease its inflow of FDI (measured as a percentage of GDP). This impact occurs rapidly. Lagged effects, while still negative, are far less in magnitude and not statistically significant. ${ }^{25}$ These findings hold when we control for the intensity of attacks and other factors commonly used in related studies (level of development, financial openness, regions, natural disasters, regional characteristics). In effect, if international terrorism is driven by grievances towards foreign countries, external debt and portfolio investment do not have the same "foreign face value" as FDI in the host economies. Expanding the analysis of the relationship between terrorism and capital flows, we examine spill-over effects on neighboring countries. We measure spill-over effects between countries according to multiple shared characteristics (geographical, cultural and their combination). We find robust evidence

\footnotetext{
${ }^{24}$ The estimations available from authors.

${ }^{25}$ This conclusion regarding timing is reinforced if we consider the possible effects of measurement error. To the extent that events in a given year contain a stochastic component, the variable Incidents may suffer from measurement error, biasing coefficients towards zero (Abadie and Gardeazabal, 2008). Thus the fact that the coefficient on this variable is still substantially larger than that on Incidents over the previous 5 years that (due to averaging) should have lower measurement error gives further evidence that timing effects are rapid.
} 
that only sharing a religion reduces FDI in a given country when attacks occur in a related country.

\section{References}

[1] Abadie, A. and Gardeazabal, J. (2008). Terrorism and the world economy. European Economic Review, 52.

[2] Charles, A. and Darne, O. (2006). Large shocks and the september 11th terrorist attacks on international stock markets. Economic Modelling, 23.

[3] Chinn, M. and Ito, H. (2008). A new measure of financial openness. Journal of Comparative Policy Analysis, 10.

[4] de Sousa, J., Mirza, D., and Verdier, T. (2010). Terrorism networks and trade: Does the neighbor hurt? CEPII research center, 04.

[5] Drakos, K. (2009). Big questions, little answers: Terrorism activity, investor sentiment and stock returns. Economics of Security Working Paper Series.

[6] Eckstein, Z. and Tsiddon, D. (2004). Macroeconomic consequences of terror: theory and the case of israel. Journal of Monetary Economics, 51(5).

[7] Enders, W., Sachsida, A., and Sandler, T. (2006). The impact of transnational terrorism on u.s. foreign direct investment. Political Research Quarterly, 59.

[8] Enders, W. and Sandler, T. (1996). Terrorism and foreign direct investment in spain and greece. Kyklos, 49 . 
[9] Enders, W. and Sandler, T. (2006). The Political Economy of Terrorism. Cambridge University Press.

[10] H.Chen, A. and Siems, T. F. (2004). The effects of terrorism on global capital markets. European Journal of Political Economy, 20.

[11] LaFree, G. (2010). The global terrorism database: Accomplishments and challenges. Perspectives on Terrorism, 4.

[12] Li, Q. and Schaub, D. (2004). Economic globalization and transnational terrorism. Journal of Conflict Resolution, 48.

[13] Mayer, T. and Zignago, S. (2011). Notes on cepii's distance measures: The geodist database. Working papers CEPII, (25).

\section{A Data Sources}

- FDI flow dataset is from UNCTAD (www.unctadstat.unctad.org);

- External Debt dataset is from World Development Indicators (www.worldbank.org);

- Portfolio equity investment dataset is from World Development Indicators (www.worldbank.org);

- Data on Population, GDP per capita is from World Development Indicators (www.worldbank.org);

- Financial Openness Index is from Chin and Ito (2009) (web.pdx.edu/ ito/ChinnIto_website.htm); 
- Data on Natural Disasters is from International Disaster Database (www.emdat.be);

- Terrorism data from Global Terrorism Database (GTD) accessed on November 2010 (www.start.umd.edu/gtd);

- Neighborhood data: border, language, colonies is from Centre d'Etudes Prospectives et d'Informations Internationales (CEPII) (www.cepii.fr);

- Religion variables are from CIA The World Factbook (www.cia.gov)

\section{B Selection of the countries in the sample}

We excluded countries that the lacked majority of the data (Andorra, American Samoa, Republic of Botswana, Channel Islands; Commonwealth Dominica, Faeroe Islands, Gibraltar, Greenland, Guam, Isle of Man, Principality of Lichtenstein, Macao, Republic of Marshall Islands, Union of Myanmar, Montenegro, Commonwealth of Northern Mariana Islands, Mayotte, New Caledonia, Nepal, Republic of Palau, Democratic People's Republic of Korea, French Polynesia, Republic of San Marino, Turks and Caicos Islands, Democratic Republic of Timor-Leste, Tuvalu, Virgin Islands of the United States, Samoa)

\section{Tables}


Table 1. Summary Statistics

\begin{tabular}{|c|c|c|c|c|c|}
\hline Variable & Obs & Mean & Std. Dev. & Min & Max \\
\hline \multicolumn{6}{|l|}{ Capital Flow variables } \\
\hline External Debt & 2668 & 3.1814 & 7.1867 & 0 & 78.7345 \\
\hline Portfolio Investments & 3165 & 0.4190 & 3.3004 & -5.5193 & 75.5732 \\
\hline FDI & 3926 & 2.6697 & 5.7611 & -65.4109 & 92.1040 \\
\hline \multicolumn{6}{|l|}{ Country variables } \\
\hline Log GDP per capita & 4023 & 7.5235 & 1.5663 & 4.1309 & 11.0527 \\
\hline Log Population (mil) & 4504 & 1.6379 & 1.9744 & -3.2156 & 7.1671 \\
\hline Financial Openness & 3725 & 0.0172 & 1.5414 & -1.8081 & 2.5408 \\
\hline Natural Disasters & 4402 & 1.7799 & 4.2738 & 0 & 83 \\
\hline \multicolumn{6}{|l|}{ Terrorism variables } \\
\hline Incidents & 4504 & 1.2031 & 6.3778 & 0 & 167.0771 \\
\hline Incidents previous 5 y average & 3609 & 1.1988 & 4.8410 & 0 & 107.8235 \\
\hline Fatalities & 4504 & 5.4843 & 40.2551 & 0 & 1139.9650 \\
\hline Fatalities 5 y.a. & 3609 & 5.4971 & 30.4917 & 0 & 576.1153 \\
\hline \multicolumn{6}{|l|}{ Spill over variables } \\
\hline Official Language & 4504 & 36.1017 & 53.2133 & 0 & 360.4344 \\
\hline Minority Language & 4504 & 42.8955 & 59.5318 & 0 & 401.0222 \\
\hline Border & 4504 & 3.1724 & 11.6129 & 0 & 231.6836 \\
\hline Common Colonizer & 4504 & 16.8149 & 32.6746 & 0 & 181.7338 \\
\hline Colony '45 & 4504 & 1.2233 & 5.3371 & 0 & 141.5415 \\
\hline Main Religion & 4504 & 40.5248 & 76.3422 & 0 & 333.9374 \\
\hline Second Religion & 4504 & 557.9299 & 3291.8190 & 0 & 72180.9500 \\
\hline \multicolumn{6}{|l|}{ Same Region and Minority } \\
\hline Religion & 4504 & 9.2256 & 27.0529 & 0 & 226.4319 \\
\hline Border and Majority Religion & 4504 & 1.9236 & 10.2108 & 0 & 231.6836 \\
\hline
\end{tabular}


Table 2. Correlation table between Capital Flows, Terrorism and Natural Dissasters

\begin{tabular}{|c|c|c|c|c|c|c|c|c|}
\hline Variables & External Debt & $\begin{array}{l}\text { Portfolio } \\
\text { Investment }\end{array}$ & FDI & Incidents & \multicolumn{2}{|c|}{ Incidents 5 y.a. Fatalities } & Fatalities 5 y.a. & $\begin{array}{l}\text { Natural } \\
\text { Disasters }\end{array}$ \\
\hline External Debt & 1 & & & & & & & \\
\hline Portfolio Investment & 0.0317 & 1 & & & & & & \\
\hline FDI & 0.131 & $0.1659 * * *$ & 1 & & & & & \\
\hline Incidents & -0.0372 & -0.0202 & $-0.0806 * * *$ & 1 & & & & \\
\hline Incidents 5 y.a. & -0.0364 & -0.0019 & $-0.0656 * * *$ & $0.73 * * *$ & 1 & & & \\
\hline Fatalities & -0.0617 & -0.0265 & $-0.0494 * * *$ & $0.751 * * *$ & $0.5325 * * *$ & 1 & & \\
\hline Fatalities 5 y.a. & -0.0364 & -0.0019 & $-0.0656 * * *$ & $0.73 * * *$ & 1 & $0.5325 * * *$ & 1 & \\
\hline Natural Disasters & $0.0769 * *$ & 0.1138 & $-0.0154 * *$ & $-0.0325^{*}$ & $-0.0364 *$ & -0.0381 & $-0.0364 *$ & 1 \\
\hline
\end{tabular}


Table 3. Fixed effects Estimation of Capital Flows and Terrorism (1980-2008)

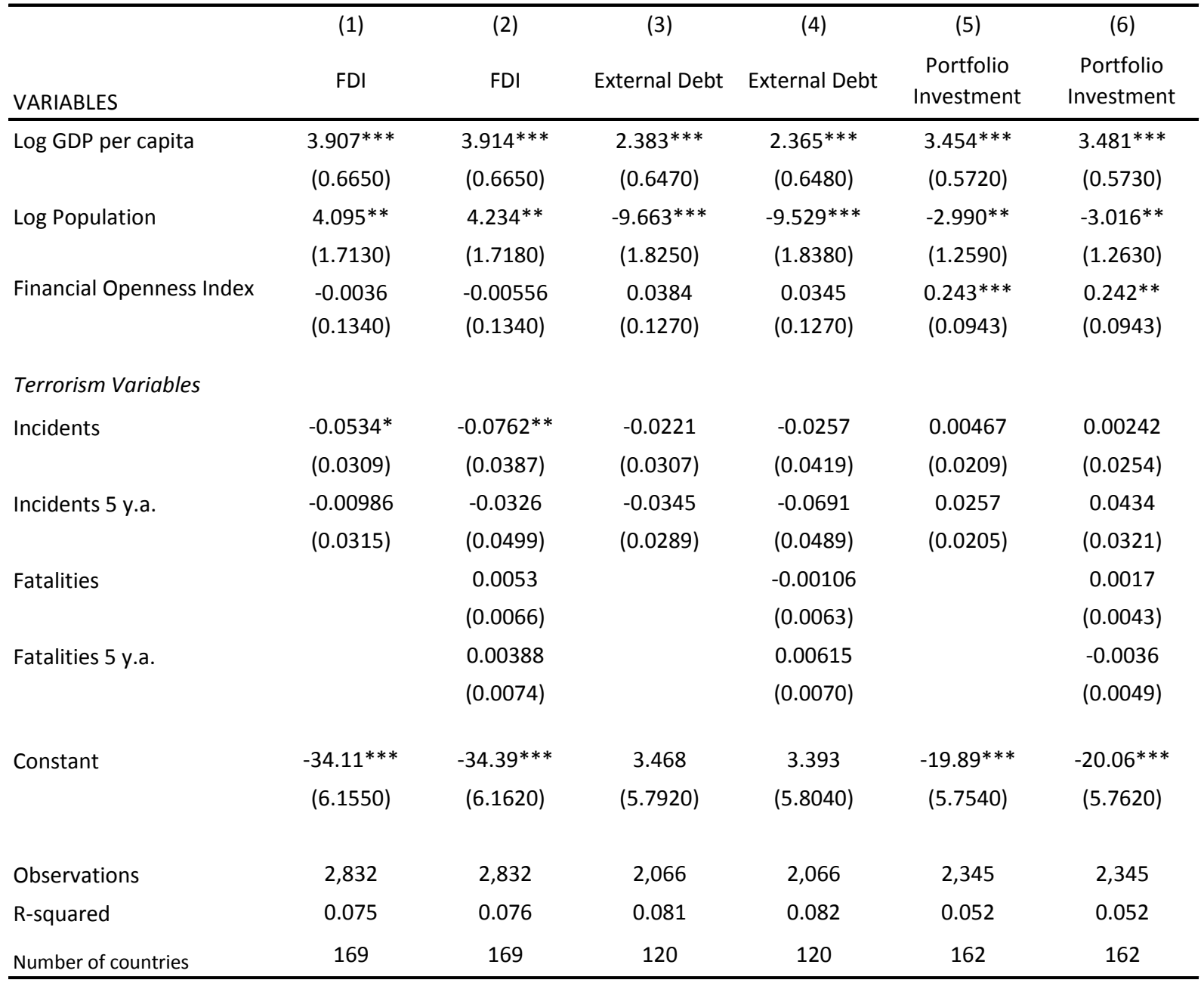

Note: Terrorism variables (Incidents; Incidents 5 y.a.; Fatalities; Fatalities 5 y.a.) are normalized by the country's population in millions. Country and year fixed effects are included in all specifications, and standard errors are reported in parentheses; ${ }^{*}, * *$, and ${ }^{* * *}$ denote significance at the $10 \%, 5 \%$, and $1 \%$ level, respectively. 
Table 4. Fixed effects Estimation of FDI and Terrorism (1980-2008)

\begin{tabular}{|c|c|c|c|c|c|c|}
\hline VARIABLES & $\begin{array}{l}\text { (1) } \\
\text { FDI }\end{array}$ & $\begin{array}{l}\text { (2) } \\
\text { FDI }\end{array}$ & $\begin{array}{l}\text { (3) } \\
\text { FDI }\end{array}$ & $\begin{array}{l}\text { (4) } \\
\text { FDI }\end{array}$ & $\begin{array}{l}\text { (5) } \\
\text { FDI }\end{array}$ & $\begin{array}{l}\text { (6) } \\
\text { FDI }\end{array}$ \\
\hline \multirow[t]{2}{*}{ Log GDP per capita } & & $3.545^{* * *}$ & $3.907 * * *$ & $3.926 * * *$ & $3.914 * * *$ & $4.094 * * *$ \\
\hline & & $(0.6480)$ & $(0.6650)$ & $(0.6650)$ & $(0.6650)$ & $(0.6840)$ \\
\hline \multirow[t]{2}{*}{ Log Population } & & & $4.095 * *$ & $4.070 * *$ & $4.234 * *$ & $4.200 * *$ \\
\hline & & & $(1.7130)$ & $(1.7170)$ & $(1.7180)$ & $(1.7170)$ \\
\hline Financial Openness & & -0.042 & -0.0036 & 0.022 & -0.00556 & 0.0141 \\
\hline Index & & $(0.1330)$ & $(0.1340)$ & $(0.1330)$ & $(0.1340)$ & $(0.1330)$ \\
\hline \multicolumn{7}{|l|}{ Terrorism Variables } \\
\hline \multirow[t]{2}{*}{ Incidents } & $-0.0631 * *$ & $-0.0547 *$ & $-0.0534 *$ & & $-0.0762 * *$ & $-0.0739 *$ \\
\hline & $(0.0302)$ & $(0.0310)$ & (0.0309) & & $(0.0387)$ & $(0.0385)$ \\
\hline \multirow[t]{2}{*}{ Incidents 5 y.a. } & -0.00879 & -0.0104 & -0.00986 & & -0.0326 & -0.0308 \\
\hline & $(0.0301)$ & $(0.0315)$ & $(0.0315)$ & & (0.0499) & $(0.0497)$ \\
\hline \multirow[t]{2}{*}{ Fatalities } & & & & -0.00211 & 0.0053 & 0.00498 \\
\hline & & & & $(0.0055)$ & $(0.0066)$ & $(0.0066)$ \\
\hline \multirow[t]{2}{*}{ Fatalities 5 y.a. } & & & & -0.00317 & 0.00388 & 0.00376 \\
\hline & & & & $(0.0044)$ & $(0.0074)$ & $(0.0074)$ \\
\hline \multirow[t]{2}{*}{ Natural Disasters } & & & & & & $-0.0745^{*}$ \\
\hline & & & & & & $(0.0416)$ \\
\hline \multirow[t]{2}{*}{ Constant } & $1.130^{* * *}$ & $-24.92 * * *$ & $-34.11 * * *$ & $-34.28 * * *$ & $-34.39 * * *$ & $-35.66 * * *$ \\
\hline & $(0.4380)$ & $(4.8090)$ & $(6.1550)$ & $(6.1650)$ & $(6.1620)$ & $(6.2590)$ \\
\hline Observations & 3,258 & 2,832 & 2,832 & 2,832 & 2,832 & 2,779 \\
\hline R-squared & 0.072 & 0.073 & 0.075 & 0.074 & 0.076 & 0.076 \\
\hline Number of countries & 180 & 169 & 169 & 169 & 169 & 165 \\
\hline
\end{tabular}

Note: Terrorism variables (Incidents; Incidents 5 y.a.; Fatalities; Fatalities 5 y.a.) are normalized by the country's population in millions. Country and year fixed effects are included in all specifications, and standard errors are reported in parentheses; ${ }^{*}, * *$, and ${ }^{* * *}$ denote significance at the $10 \%, 5 \%$, and $1 \%$ level, respectively. 
Table 5. Fixed effects Estimation of FDI, Terrorism, and Terrorism Spill-over (1980-2008)

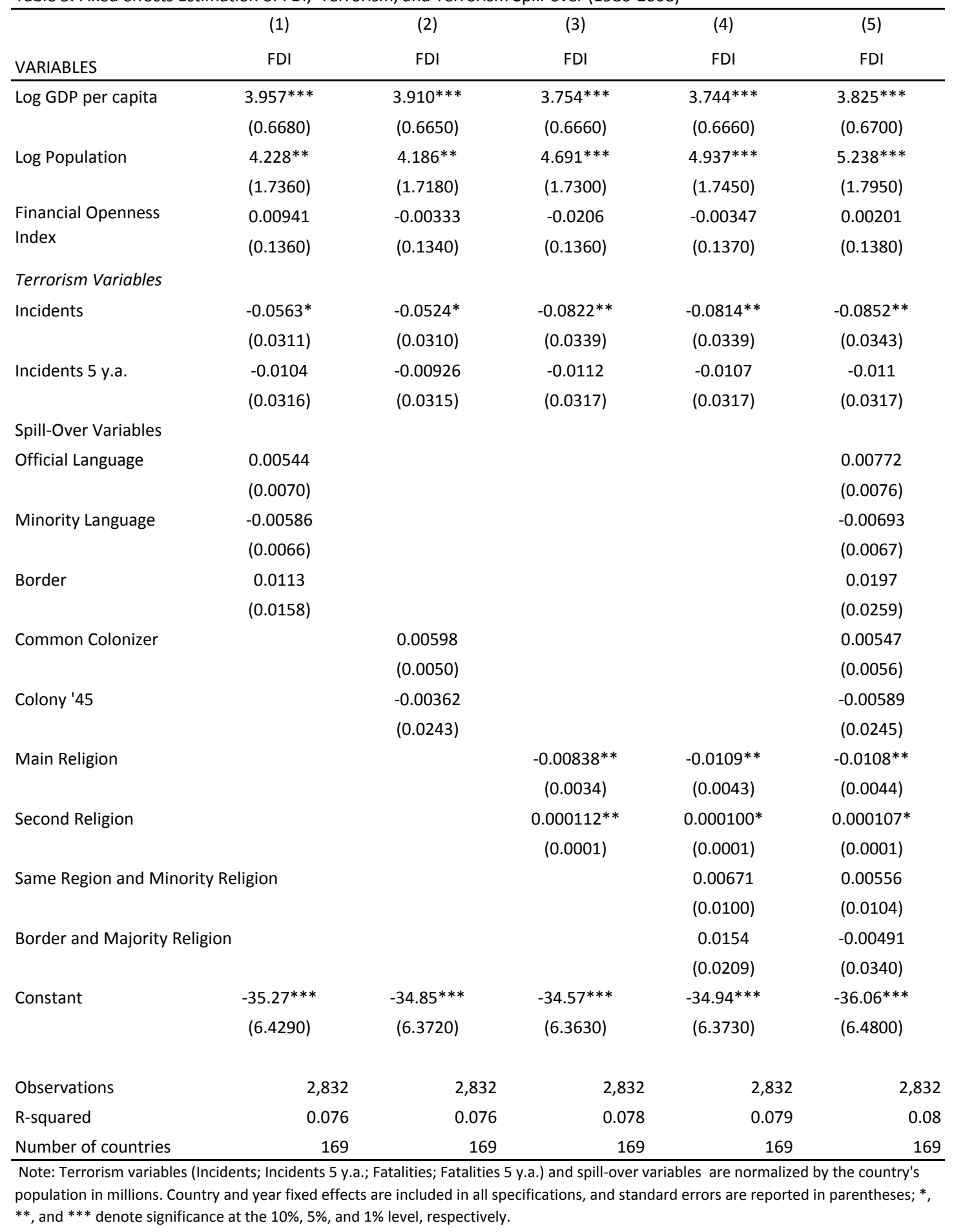




\section{Working Paper Series}

ISSN 1211-3298

Registration No. (Ministry of Culture): E 19443

Individual researchers, as well as the on-line and printed versions of the CERGE-EI Working Papers (including their dissemination) were supported from institutional support RVO 67985998 from Economics Institute of the ASCR, v. v. i.

Specific research support and/or other grants the researchers/publications benefited from are acknowledged at the beginning of the Paper.

(c) Randall K. Filer and Dragana Stanišić, 2013

All rights reserved. No part of this publication may be reproduced, stored in a retrieval system or transmitted in any form or by any means, electronic, mechanical or photocopying, recording, or otherwise without the prior permission of the publisher.

Published by

Charles University in Prague, Center for Economic Research and Graduate Education (CERGE) and

Economics Institute ASCR, v. v. i. (EI)

CERGE-EI, Politických vězňů 7, 11121 Prague 1, tel.: +420 224005 153, Czech Republic.

Printed by CERGE-EI, Prague

Subscription: CERGE-EI homepage: http://www.cerge-ei.cz

Phone: + 420224005153

Email: office@cerge-ei.cz

Web: http://www.cerge-ei.cz

Editor: Michal Kejak

The paper is available online at http://www.cerge-ei.cz/publications/working_papers/.

ISBN 978-80-7343-284-3 (Univerzita Karlova. Centrum pro ekonomický výzkum a doktorské studium)

ISBN 978-80-7344-276-7 (Národohospodářský ústav AV ČR, v. v. i.) 
CERGE-EI

P.O.BOX 882

Politických vězňů 7

11121 Praha 1

Czech Republic http://www.cerge-ei.cz 